\title{
PENGARUH POLA ASUH ORANG TUA TERHADAP PEMBENTUKAN KEPRIBADIAN ANAK-ANAK DI TAMAN KANAK-KANAK AS-SALAM KECAMATAN. ALAM BARAJO KOTA JAMBI
}

\author{
Lidarnita \\ TK AS-SALAM Kota Jambi \\ Email: lidarnita3@gmail.com
}

\begin{abstract}
ABSTRAK
Pola asuh orang tua sangat mempengaruhi setiap kepribadian yang telah terbentuk. Segala gaya atau model pengasuhan orang tua akan membentuk suatu kepribadian yang berbeda-beda sesuai apa yang telah diajarkan oleh orang tua. Orang tua merupakan lingkungan pertama bagi anak yang sangat berperan penting dalam setiap perkembangan anak khususnya perkembangan kepribadian anak. Oleh karena itu, diperlukan cara yang tepat untuk mengasuh anak sehingga terbentuklah suatu kepribadian anak yang diharapkan oleh orang tua sebagai harapan masa depan.

Dalam pengasuhan anak orang tua harus mamperhatikan tingkat perkembangan anak. Semua perilaku orang tua yang baik atau buruk akan ditiru oleh anak, oleh karena itu perlunya orang tua untuk menjaga setiap perilakunya sehingga anak akan meniru sikap positif dari orang tua. Pola asuh orang tua harus disesuaikan dengan situasi dan kondisi anak pada saat itu, ada kalanya orang tua bersikap demokratis, ada kalanya juga harus bersikap otoriter, ataupun bersikap permisif.
\end{abstract}

\section{Kata Kunci: Pola asuh orang tua, Kepribadian anak}

\section{A. PENDAHULUAN}

\section{a. Latar Belakang}

Masa lima sampai enam tahun pertama kehidupan anak sebagaimana yang tertera pada modul yang diterbitkan oleh Depdiknas (2009:1), anak TK merupakan masa di mana perkembangan kognitif, motorik, intelektual, emosional, bahasa dan sosial berlangsung dengan sangat cepat sehingga menentukan masa depan anak. Di masa inilah semua perkembangan anak mulai terbentuk dan cenderung menetap sampai usia dewasa. Dengan demikian betapa pentingnya pendidikan awal bagi anak TK yang memberikan bekal untuk mempersiapkan diri menerima pengajaran bagi kehidupan selanjutnya.

Usia prasekolah adalah usia yang rentan bagi anak. Pada usia ini anak mempunyai sifat imitasi atau meniru terhadap apapun yang telah dilihatnya. Orang-orang dewasa yang paling dekat dengan anak adalah orang tua. Keluarga 
merupakan lingkungan pertama dan utama bagi anak yang mempunyai pengaruh besar. Haryoko (1997: 2) berpendapat bahwa lingkungan sangat besar pengaruhnya sebagai stimlans dalam perkembangan anak. Orang tua mempunyai peranan yang sangat besar dalam pembentukan kepribadian anak.

Kenyataan yang terjadi di masyarakat, bahwa tanpa disadari semua perilaku serta kepribadian orang tua yang baik ataupun tidak ditiru anak. Anak tidak mengetahui apakah yang telah dilakukannya baik atau tidak, karena anak usia prasekolah belajar dari apa yang dia lihat. Pembelajaran tentang sikap, perilaku dan bahasa yang baik sehingga akan terbentuknya kepribadian anak yang baik pula, perlu diterapkan sejak dini. Orang tua merupakan pendidik yang paling utama, guru serta teman sebaya yang merupakan lingkungan kedua bagi anak. Hal ini sesuai dengan pendapat Hurlock (1978) yang mengungkapkan bahwa orang yang paling penting bagi anak adalah orang tua, guru dan teman sebaya dari merekalah anak mengenal sesuatu yang baik dan tidak baik. Pendidikan dalam keluarga yang baik dan benar, akan sangat berpengaruh pada perkembangan pribadi dan sosial anak. Kebutuhan yang diberikan melalui pola asuh, akan memberikan kesempatan pada anak untuk menunjukkan bahwa dirinya adalah sebagian dari orang-orang yang berada disekitarnya. Berdasarkan uraian tersebut, dapat disimpulkan bahwa pola asuh orang tua mempunyai pengaruh yang sangat besar terhadap pembentukan kepribadian anak.

Usia prasekolah merupakan usia yang sangat strategis untuk menerima rangsangan-rangsangan dari luar, melalui pemberian rangsangan-rangsangan positif untuk pertumbuhan dan perkembang anak menjadi maksimal. Kematangan kognitif pada anak prasekolah, secara garis besar, Piaget (dalamSuparno, 2001:24-25), mengelompokkan menjadi empat tahap, yaitu tahap sensorimotor (0-2 tahun), tahap praoperasi (2-7 tahun), tahap operasi konkret (7-11 tahun) dan tahap operasi formal (11 tahun dewasa). Tahap sensorimotor lebih ditandai dengan pemikiran anak berdasarkan tindakan inderawi. Tahap praopcrasi diwarnai dengan mulai digunakannya simbol-simbol untuk menghadirkan suatu benda atau pemikiran khususnya penggunaan bahasa. Tahap operasi konkret ditandai dengan penggunaan aturan logis dan jelas. Tahap operasi formal dicirikan dengan pemikiran abstrak, hipotesis, deduktif serta induktif. Tahap-tahap 
tersebut saling berkaitan. Urutan tahap-tahap tidak dapat ditukar atau dibalik, karena tahap sesudahnya mengandaikan terbentuknya tahap sebelumnya.

Maka berdasarkan uraian latar belakang tersebut di atas, maka penulis mengambil judul "Pengaruh Pola Asuh Orang Tua Terhadap Pembentukan Kepribadian Anak-Anak di Taman Kanak-Kanak As-Salam Kecamatan. Alam Barajo. Kota Jambi.

\section{b. Rumusan Masalah}

Dari latar belakang diatas maka rumusan masalah pada penelitian ini, antara lain:

1. Apa pengertian pola asuh orang tua?

2. Apa itu kepribadian?

3. Apa saja macam-macam pola asuh orang tua?

4. Bagaimana pengaruh pola asuh orang tua terhadap pembentukan kepribadian anak?

\section{Tujuan Penelitian}

Tujuan dari penelitian ini adalah sebagai berikut:

1. Untuk menjelaskan apa yang dimaksud pola asuh orang tua.

2. Untuk menjelaskan apa yang dimaksud dengan kepribadian.

3. Untuk mendiskriprisikan macam-macam pola asuh orang tua.

4. Untuk mendiskripsikan pengaruh pola asuh orang tua terhadap pembentukan kepribadian anak usia dini.

\section{Manfaat Penelitian}

Adapun manfaat penelitian ini adalah :

1. Manfaat Teoritis

a. Sebagai pendorong untuk pelaksanaan pendidikan sehingga menjadi pengetahuan bagi orang tua dan guru.

b. Sebagai informasi pengetahuan untuk meningkatkan kemampuan berhitung pada anak. 
2. Manfaat Praktis

- Bagi anak didik

1) Membantu anak menemukan dan memahami konsep-konsep yang sulit.

2) Mendorong semangat belajar anak didik terhadap pelajaran berhitung.

3) Menanamkan pengertian bilangan dan kecakapan dasar berhitung.

4) Memupuk dan mengembangkan kemampuan berpikir logis dan kritis dalam memecahkan masalah yang dihadapi dikehidupan sehari-hari baik sekarang dan masa mendatang.

- Bagi guru

1) Memudahkan guru untuk melatih ketrampilan dan kesabaran dalam mengajarkan pelajaran berhitung.

2) Membangkitkan kreativitas guru dalam menerapkan dan menciptakan inovasi dalam kegiatan pembelajaran.

- Bagi sekolah

1) Kegiatan pembelajaran di kelas akan lebih efektif dan efisien.

2) Sekolah akan mampu mengembangkan model-model pembelajaran.

3) Sekolah akan mampu menghasilkan sumber daya yang berkualitas

\section{B. KAJIAN PUSTAKA}

\section{Pengertian Pola Asuh Orang Tua}

Pola asuh orang tua adalah pola perilaku yang diterapkan pada anak dan bersifat konsisten dari waktu ke waktu. Pola perilaku ini dapat dirasaka oleh anak, dari segi negatif dan positif. Istilah kepribadian merupakan terjemahan dari bahasa inggris "Personality". Secara etimologis, kata personality berasal dari bahasa latin "persona" yang berarti topeng. Menurut Gordon W All Port" Personality is the dynamic organization whitin the individual of those psychophysical system, that determines his unique adjustment to his environment". Menurut bangsa Roma, persona berarti” bagaimana seseorang tampak pada orang lain", bukan dari sebenarnya. Aktor menciptakan dalam pikiran penonton, suatu impresi dari tokoh yang diperankan diatas pentas, bukan 
impresi dari tokoh itu sendiri. Dari konotasi kata persona inilah, gagasan umum mengenai kepribadian sebagai kesan yang diberikan seseorang pada orang lain diperoleh.

Apa yang dipikir, dirasakan dan siapa dia sesungguhnya ternasuk dalam keseluruhan "make up" psikologis seseorang dan sebagian besar terungkapkan melalui perilaku, karena itu kepribadian bukanlah suatu atribut yang pasti dan spesifik, melainkan merupakan kualitas perilaku total seseorang. Berdasarkan definisi All Port dapat disimpulkan bahwa, Kepribadian ialah susunan sistemsistem psikofisik yang dinamai dalam diri suatu individu yang unik terhadap lingkungan.

\section{Macam-macam Pola Asuh Orang Tua}

a. Pola asuh demokratis

Pola asuh demokratis adalah pola asuh yang memprioritaskan kepentingan anak, akan tetapi tidak ragu-ragu mengendalikan mereka. Orang tua dengan pola asuh ini bersiap rasional, selalu mendasari tindakannya pada rasio atau pemikiran-pemikiran. Orang tua tipe ini juga bersikap realistik terhadap kemampuan anak, tidak berharap yang berlebihan yang melampaui kemampuan anak. Orang tua tipe ini juga memberikan kebebasan kepada anak untuk memilih dan melakukan suatu tindakan dan pendekatannya kepada anak bersifat hangat.

b. Pola asuh Otoriter

Pola asuh ini cenderung menetapkan standar yang mutlak harus dituruti, biasanya diikuti dengan ancaman-ancaman. Orang tua tipe ini cenderung memaksa, memerintah, menghukum. Hukuman mental dan fisik akan sering diterima oleh anak-anak dengan alasan agar anak terus tetap patuh dan disiplin serta menghormati orang-tua yang telah membesarkannya. Apabila anak tidak mau melakukan apa yang dikatakan oleh orang tua, maka orang tua tipe ini tidak segan menghukum anak. Terlebih lagi orang tua tipe ini tidak mengenal kompromi dan dalam komunikasi biasanya bersifat satu arah. 
c. Pola asuh Permisif

Pola asuh permisif adalah jenis pola mengasuh anak yang cuek terhadap anak. Biasanya pola pengasuhan anak oleh orang tua semacam ini diakibatkan oleh orang tua yang terlalu sibuk dengan pekerjaan, kesibukan atau urusan lain yang akhirnya lupa untuk mendidik dan mengasuh anak dengan baik. Dengan begitu anak hanya diberi materi atau harta saja dan terserah anak itu tumbuh dan berkembang menjadi apa. Anak yang diasuh orang tua nya dengan metode semacam ini nantinya bisa berkembang menjadi anak yang kurang perhatian, merasa tidak berarti, rendah diri, nakal, memiliki kemampuan sosialisasi yang buruk, kontrol diri buruk, salah bergaul, kurang menghargai orang lain, dan lain sebagainya baik ketika kecil maupun sudah dewasa.

\section{Pola Asuh Orang Tua Terhadap Pembentukan Kepribadian Anak}

Anak prasekolah belajar cara berinteraksi dengan orang lain dengan mencontoh, berbagi dan menjadi teman baik. Mereka juga mempelajari sikap, nilai, prefensi pribadi dan beberapa kebiasaan dengan mengikuti contoh, termasuk cara mengenali dan menangani emosi mereka. Anak prasekolah belajar banyak dari perilaku orang-orang disekitar mereka. Keluarga adalah kelompok sosial pertama dengan siapa anak diidentifikasikan, anak lebih banyak menghabiskan waktunya dengan kelompok keluarga daripada dengan kelompok sosial lainnya. Anggota keluarga merupakan orang yang paling berarti dalam kehidupan anak.

\section{Pola Asuh Orang Tua dengan Tingkat Ekonomi Menengah Keatas dan Menengah Kebawah}

Permasalahan ekonomi dalam keluarga merupakan masalah yang sering dihadapi. Tanpa disadari bahwa permasalahan ekonomi dalam keluarga akan berdampak pada anak. Orang tua terkadang melampiaskan kekesalan dalam menghadapi permasalahan pada anak. Anak usia prasekolah yang belum mengerti tentang masalah perekonomian dalam keluarga hanya akan menjadi korban dari orang tua. Dalam pola asuh yang diberikan oleh orang tua yang tingkat 
perekonomiannya menengah keatas dan orang tua yang tingkat perekonomiannya menengah kebawah berbeda. Orang tua yang tingkat perekonominnya menengah keatas dalam pengasuhannya biasanya orang tua memanjakan anaknya. Apapun yang diinginkan oleh anak akan dipenuhi orang tua. Segala kebutuhan anak dapat terpenuhi dengan kekayaan yang dimiliki orang tua. Pengasuhan anak sebagian besar hanya sebatas dengan materi.

Perhatian dan kasih sayang orang tua diwujudkan dalam materi atau pemenuhan kebutuhan anak. Anak yang terbiasa dengan pola asuh yang demikian, maka akan membentuk suatu kepribadian yang manja, serba menilai sesuatu dengan materi dan tidak menutup kemungkinan anak akan sombong dengan kekayaan yang dimiliki orang tua serta kurang menghormati orang yang lebih rendah darinya. Sedangkan pada orang tua yang tingkat perekonomiannya menengah kebawah dalam cara pengasuhannya memang kurang dapat memenuhi kebutuhan anak yang bersifat materi. Orang tua hanya dapat memenuhi kebutuhan anak yang benar-benar penting bagi anak. Perhatian dan kasih sayang orang tualah yang dapat diberikan.

Anak yang hidup dalam perekonomian menengah kebawah terbiasa hidup dengan segala kekurangan yang dialami keluarga. Sehingga akan terbentuk kepribadian anak yang mandiri, mampu menyelesaikan permasalahan dan tidak mudah stres dalam menghadapi suatu permasalahan.dan anak dapat menghargai usaha orang lain. Pada kenyataannya terdapat juga anak yang minder dengan keadaan ekonomi orang tua yang kurang. Oleh karena itu, peran orang tua dalam hal ini sangat penting. Orang tua harus menyeimbangkan dengan pendidikan agama pada anak. Sehingga anak mampu mensyukuri segala yang telah diberikan oleh sang Pencipta.

\section{METODE PENELITIAN}

\section{Jenis Penelitian}

Jenis penelitian yang digunakan yaitu Penelitian Tindakan Kelas. Penelitian tindakan kelas adalah penelitian yang dilakukan oleh guru dan di monitorkan oleh Kepala Sekolah di dalam kelasnya sendiri melalui refleksi diri 
dengan tujuan untuk memperbaiki kinerjanya sebagai guru, sehingga hasil belajar siswa menjadi meningkat.

\section{Tempat Dan Waktu Penelitian}

Penelitian yang dilakukan penulis mengambil lokasi di Taman Kanakkanak As-Salam Kecamatan. Alam Barajo Kota Jambi. Adapun penelitian dilaksanakan, pada semester genap 2019-2020.

\section{Subjek Penelitian.}

Subjek penelitian ini adalah siswa kelompok B TK As-Salam Kecamatan Alam Barajo Kota Jambi yang berjumlah 48 siswa.

\section{Rancangan Penelitian}

Penelitian tindakan ini dilaksanakan dalam dua siklus kegiatan yaitu siklus 1 dan siklus 2. Masing-masing siklus terdiri 4 tahap kegiatan yaitu :

a. Menyusun rencana tindakan

b. Melaksanakan tindakan

c. Melakukan observasi

d. Membuat analisis dilanjutkan refleksi

Pada penelitian ini yang melaksanakan kegiatan mengajar adalah guru kelas kelompok B sebagai peneliti bersama-sama dengan guru kelompok A yang bertindak sebagai observer.

\section{SIKLUS - 1}

1. Penyusunan rencana tindakan 1

Pada tahap ini peneliti menyusun rencana pembelajaran berdasarkan pokok bahasan dan tema yang akan diajarkan dengan tujuan untuk kemampuan berhitung yang meliputi merumuskan tujuan pembelajaran, menyusun langkahlangkah pembelajaran, merencanakan alat peraga (media) apa yang sesuai pokok bahasan yang akan diajarkan dari bagaimana menggunakannya, serta menyusun alat evaluasi yang sesuai dengan tujuan. 


\section{Pemberian tindakan 1}

Pada kegiatan awal pembelajaran guru melakukan kegiatan tanya jawab tentang kondisi anak ataupun dengan benda-benda di sekitar anak yang berhubungan dengan materi yang akan diajarkan, siswa beri tugas untuk mengamati dan melihat media yang telah disediakan, kemudian siswa diminta untuk melakukan permainan yang telah di buat.

\section{Melakukan observasi}

Pada waktu kegiatan pembelajaran berlangsung, guru kelompok B yang bertindak sebagai peneliti bersama guru kelompok A melakukan observasi dan mencatat kejadian-kejadian selama kegiatan pembelajaran berlangsung yang nantinya dapat bermanfaat untuk pengambilan keputusan apakah guru dapat menggunakan media dengan tepat atau perlu diadakan tindak lanjut.

4. Pembuatan analisis dan refleksi

Dari hasil observasi dilakukan analisis pada tindakan 1 kemudian dilanjutkan dengan refleksi. Berdasarkan hasil analisis dan refleksi yang dilakukan bersama-sama ini, direncanakan perbaikan dengan melakukan tindakan 2 terhadap permasalahan-permasalahan yang masih ada.

\section{SIKLUS - 2}

1. Penyusunan rencana tindakan 2

Rencana tindakan 2 disusun berdasarkan hasil analisis dan refleksi selama siklus 1 .

2. Pembelajaran tindakan 2

Tindakan 2 ini dilakukan terhadap permasalahan yang masih ada pada siklus 1. Diharapkan pada akhir tindakan 2, permasalahan guru dan siswa dalam pembelajaran dengan melihat perkembangan setiap peserta didik setiap hari dalam segala aspek pendidikan anak baik di dalam maupun luar ruangan.

3. Pelaksanaan observasi

Pada waktu kegiatan pembelajaran berlangsung, Kepala Sekolah di bantu oleh guru kelompok B dan kelompok A yang bertindak sebagai peneliti melakukan observasi dan mencatat kejadian-kejadian selama kegiatan 
pembelajaran berlangsung yang nantinya dapat bermanfaat untuk pengambilan keputusan apakah guru dapat menggunakan media dengan tepat atau perlu diadakan tindak lanjut.

4. Pembuatan analisis dan refleksi

Pada akhir tindakan 2 dilakukan analisis dan refleksi terhadap kegiatan yang telah dilakukan. Dan hasil analisis dan refleksi ini disusun kesimpulan dan saran dari seluruh kegiatan pada siklus 2 .

\section{Teknik Pengumpulan Data}

Dalam penelitian ini ada 2 teknik pengumpulan data yaitu observasi dan penugasan atau pemberian tugas.

1. Observasi

Cara pengumpulan data untuk mendapatkan informasi dengan cara pengamatan langsung terhadap sikap/perilaku guru dan anak. Tujuannya adalah mengamati peristiwa yang dirasakan subjek dan untuk mengembangkan pemahaman tentang kognitif ( berhitung ) secara kompleks yang dimiliki anak.

Format Observasi.

\begin{tabular}{|c|c|c|c|c|c|}
\hline No & Observasi & SB & B & $\mathrm{C}$ & $\mathbf{K}$ \\
\hline \multicolumn{6}{|c|}{ Guru } \\
\hline 1 & Kesiapan guru & & & & \\
\hline 2 & Membuat RKH & & & & \\
\hline 3 & Alat atau sarana prasarana & & & & \\
\hline 4 & $\begin{array}{l}\text { Mempersiapkan kelas sesuai dengan tema dan } \\
\text { kegiatan yang dilakukan }\end{array}$ & & & & \\
\hline 5 & Penguasaan materi & & & & \\
\hline \multicolumn{6}{|c|}{ Siswa } \\
\hline 1 & Perilaku siswa & & & & \\
\hline 2 & Kreatifitas siswa & & & & \\
\hline 3 & Hasil belajar siswa & & & & \\
\hline
\end{tabular}


Keterangan:

$$
\begin{array}{clcr}
\text { SB } & \text { : Sangan baik } & \text { C } & \text { : Cukup } \\
\text { B } & \text { : Baik. } & \text { K } & \text { : Kurang }
\end{array}
$$

2. Penugasan atau pemberian tugas

Suatu penelitian dimana guru dapat memberikannya setelah melihat hasil kerja anak. Pemberian tugas dapat dilakukan secara kelompok atau individu.

Tujuannya ialah untuk mengetahui sejauh mana hasil kerja anak selama dalam mengikuti proses belajar mengajar atau menerima materi.

\section{Sumber Data}

Data yang dikumpulkan dalam penelitian ini berupa catatan-catatan, rencana persiapan mengajar, hasil observasi terhadap kegiatan pembelajaran dan hasil tugas atau pekerjaan siswa. Adapun sumber data dalam penelitian ini adalah:

1. Data yang didapat dari kegiatan anak yang diamati selama proses kegiatan berlangsung dilakukan melalui observasi atau pengamatan langsung yang mana hasilnya ditulis dalam lembaran observasi.

2. Data dari hasil kegiatan anak dapat dilihat dalam proses kegiatan anak berlangsung.

\section{Teknik Analisis Data}

Penulis menggunakan tanda penilaian berupa angka yang memiliki kriteria sebagai berikut:

1) Nilai 4: sangat baik

2) Nilai 3: baik

3) Nilai 2: cukup baik

4) Nilai 1: kurang baik

Teknik analisis data yang digunakan untuk mengolah data dihasilkan dari menggunakan rumus (Suharsimi Arikunto,1998

\section{Keterangan:}

$$
\begin{aligned}
& \mathbf{x}=\text { nilai rata-rata } \\
& \mathrm{n}=\text { jumlah jawaban } \\
& \mathrm{N}=\text { jumlah anak }
\end{aligned}
$$




\section{1, 2, 3, 4 = bobot atau skor jawaban}

Prosentase keseluruhan analisis data dari penilaian anak dalam kegiatan pembelajaran dihitung dengan menggunakan rumus (Fuad Amsyari)

$$
\begin{aligned}
& \text { Keterangan: } \\
& \begin{aligned}
\mathrm{X} & =\text { nilai rata-rata } \\
& =\text { presentase masing-masing kriteria }
\end{aligned} \\
& \mathrm{N}=\text { jumlah anak }
\end{aligned}
$$

Seorang anak dikatakan mencapai ketuntasan jika taraf penguasaan lebih dari $75 \%$ dan belum mencapai ketuntasan apabila taraf penguasaan kurang dari $75 \%$

\section{HASIL DAN PEMBAHASAN PENELITIAN}

\section{Deskripsi Hasil dan Pembahasan Penelitian}

Dari hasil wawancara peneliti memperoleh informasi bahwa semua wali murid atau orang tua TK As-Salam rata-rata telah menerapkan pola asuh yang baik. Hal itu di buktikan dengan pendidikan karakter yang cukup baik yang di miliki oleh terhadap masing-masing anak di TK As-Salam. Adanya rasa tanggung jawab, santun dalam berbicara dan sopan dalam berprilaku. Dan adanya rasa jiwa tampil berani di depan umum bila di tunjuk oleh guru untuk maju ke depan. Dari segi pengetahuan agama baik bacaan sholat dan hapalannya pun sudah banyak dikuasai dengan sangat baik.

Rumusan kegiatan siswa pada komponen langkah-langkah kegiatan pembelajaran anak cukup tajam, interaktif, inspiratif, menantang, dan sistematis. Dilihat dari segi interaksi amak dan guru terjadi peningkatan dalam hal pembelajaran baik di dalam ruangan maupun di luar ruangan..

\section{Pembahasan}

Penelitian Tindakan Sekolah dilaksanakan di TK As-Salam Kecamatan. Alam Barajo Kota Jambi yang merupakan sekolah tempat peneliti bertugas sebagai kepala sekolah berstatus swasta, terdiri atas 11 orang guru.. Selanjutnya 
dilihat dari kompetensi guru dalam menilai kepribadian anak terjadi peningkatan dari waktu ke waktu.

Guru dapat mengetahui kepribadian atau karakteristik anak dari kegiatan hari-hari dalam pembelajaran, yang di awali Pada tahap pertama semua guru (11 orang) mencantumkan identitas mata pelajaran dalam RKH-nya (melengkapi RKH-nya dengan identitas mata pelajaran). Pada tahap kedua guru tersebut mencantumkan identitas mata pelajaran dalam RKH-nya. Di dalam pembelajaran guru dapat sambil memperhatikan perkembangan anak dari semua aspek ternasuk di dalamnya hal yang mengenai kepribadian anak. Tingkah laku sehari-hari di kelas, bersikap ketika berbicara dengan guru, teman, ketika belajar, bersabar ketika mengantri, bersabar ketika mendapat barang ia senangi, bersabar ketika barang yang ia senangi tidak sengaja di rusak oleh temannya. Dan tata cara anak tersebut bila sedang melaksanakan sholat dhuha berjamaah.

Pola asuh orang tua atau wali murid TK As-Salam di rumah terhadap anak sangat mempengaruhi setiap kepribadian yang telah terbentuk. Segala gaya atau model pengasuhan orang tua akan membentuk suatu kepribadian yang berbedabeda sesuai apa yang telah diajarkan oleh orang tua. Orang tua merupakan lingkungan pertama bagi anak yang sangat berperan penting dalam setiap perkembangan anak khususnya perkembangan kepribadian anak. Oleh karena itu, diperlukan cara yang tepat untuk mengasuh anak sehingga terbentuklah suatu kepribadian anak yang diharapkan oleh orang tua sebagai harapan masa depan.

Pola asuh yang baik untuk pembentukan kepribadian anak adalah pola asuh orang tua yang memprioritaskan kepentingan anak, akan tetapi dengan pengawasan dan pengendalian orang tua. Sehingga terbentuklah karakteristik anak yang dapat mengontrol diri, anak yang mandiri, mempunyai hubungan yang baik dengan teman, mampu menghadapi stres dan mempunyai minat terhadap hal-hal baru.

(Berdasarkan hasil Observasi dan Wawancara oleh peneliti pada tanggal, 17 Januari 2019 di TK As-Salam Kota Jambi) Sikap orang tua yang dapat mendukung dalam pembentukan kepribadian anak antara lain: Penanaman 
pekerti sejak dini, mendisiplinkan anak, menyayangi anak secara wajar, menghindari pemberian label "malas" pada anak, hati-hati dalam menghukum anak, strategi dalam pembentukan kepribadian anak, tekankan segi positif, Jaga agar peraturan tetap sederhana, bersikap proaktif, mengarahkan kembali perilaku yang salah, mengatasi transisi, negosiasi dan kompromi, jangan membuat alasan, hindari kontrol lewat rasa bersalah.

Dalam cara pengasuhan orang tua yang bekerja dan orang tua yang tidak bekerja berbeda. Begitu pula dengan gaya pengasuhan orang tua yang mempunyai pendidikan yang tinggi dan orang tua yang mempunyai pendidikan yang rendah. Dan juga pola asuh orang tua yang tingkat perekonomian menengah keatas dan orang tua yang perekonomiannya menengah kebawah. Masing-masing pola asuh yang telah diberikan orang tua mempunyai pengaruh yang besar tehadap pembentukan kepribadian anak.

\section{E. PENUTUP}

\section{Kesimpulan}

Pola asuh orang tua sangat mempengaruhi setiap kepribadian yang telah terbentuk. Segala gaya atau model pengasuhan orang tua akan membentuk suatu kepribadian yang berbeda-beda sesuai apa yang telah diajarkan oleh orang tua. Orang tua merupakan lingkungan pertama bagi anak yang sangat berperan penting dalam setiap perkembangan anak khususnya perkembangan kepribadian anak. Oleh karena itu, diperlukan cara yang tepat untuk mengasuh anak sehingga terbentuklah suatu kepribadian anak yang diharapkan oleh orang tua sebagai harapan masa depan.

\section{Saran}

Dalam pengasuhan anak orang tua harus mamperhatikan tingkat perkembangan anak. Semua perilaku orang tua yang baik atau buruk akan ditiru oleh anak, oleh karena itu perlunya orang tua untuk menjaga setiap perilakunya sehingga anak akan meniru sikap positif dari orang tua. Pola asuh orang tua harus disesuaikan dengan situasi dan kondisi anak pada saat itu, ada kalanya orang tua 
bersikap demokratis, ada kalanya juga harus bersikap otoriter, ataupun bersikap permisif.

\section{DAFTAR PUSTAKA}

Hurlock, Elizabeth. B. 1999. Perkembangan Anak Jilid 2. Jakarta: Erlangga

Nuraeni. 2006. Pengaruh Pola Asuh Orang Tua Tehadap Pembentukan Kepribadian Anak Taman Kanak-Kanak.

http://digilib.unnes.ac.id/gsdl/collect/skripsi/archives/HASH9d3a.dir/doc.pdf

Anonim. 2006. Lentera Kehidupan Pendidikan Anak.

Suparno, Paul, 2001, Teori Perkembangan Kognitif Jean Piaget, Yogyakarta: Kanisius.

Undang-Undang Republik Indonesia Nomor 20 Tahun 2003 tentang Sistem

Pendidikan Nasional, 2004, Bandung: Citra Umbara.

Jakarta, Dirjen Manajemen Dikdasmen, Direktorat Pembinaan TKdan SD.

Dirjen Manajemen Dikdasmen, Pedoman Pembelajaran Kognitif Di Taman KanakKanak, Jakarta, Dirjen Manajemen Dikdas. 2007.

Rika Ariyani, Editor Jurnal Literasiologi. Literasi Kita Indonesia. STAI Syekh Maulana Qori. Merangin Bangko. 